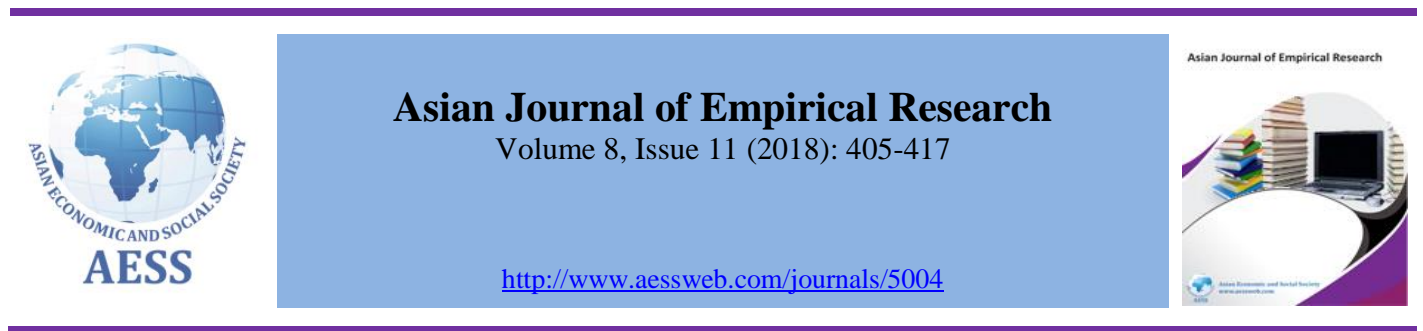

\title{
Examination of bank-specific and macroeconomic determinants of Islamic banks profitability in Bangladesh: a panel data approach
}

\author{
Muhammad Enamul Haque in and Nusrat Farzana \\ Assistant Professor; School of Business and Economics, United International University, Madani \\ Avenue, Badda, Dhaka-1212, Bangladesh. \\ \meh@bus.uiu.ac.bd Corresponding author
}

\section{ARTICLE HISTORY:}

Received: 13 -Aug-2018

Accepted: 06-Dec-2018

Online available: $24-\mathrm{Dec}-$

2018

\section{Keywords:}

Islamic banks,

Endogenous and exogenous variables,

Static panel data approach,

Huasman test etc

\begin{tabular}{l}
\hline A B S T RA C T \\
Islamic banks have continued to demonstrate tremendous growth \\
over the last decade as reflected by its increasing market shares in \\
terms of deposits and investments compared to the total banking \\
system. This study makes an effort to examine the bank-specific and \\
macroeconomic determinants of eight full-fledged Islamic banks \\
profitability in Bangladesh applying two static linear panel data \\
approaches. The study uses return on assets, return on equity and \\
net investment margin as measures of profitability. The results \\
indicate that bank-specific variables such as capital to risk based \\
assets, liquidity, bank size, and operating efficiency are highly \\
correlated with Islamic banks profitability. Both the \\
macroeconomic variables are found to be statistically nugatory and \\
do not have any influence to affect the Islamic bank profitability.
\end{tabular}

\section{Contribution/ Originality}

Most of the previous studies have been on determinants of conventional banks profitability in Bangladesh and until now there has been virtually no study to determine the profitability of only fullfledged Islamic banks in Bangladesh. This paper used all three profitability measurement variables in a single study documented from various empirical studies. This study will help researchers and policy makers to reshape their decisions for enriching the potential outcomes.

DOI: 10.18488/journal.1007/2018.8.11/1007.11.405.417

ISSN (P): 2306-983X, ISSN (E): 2224-4425

CrossMark

How to cite: Muhammad Enamul Haque and Nusrat Farzana (2018). Examination of bank-specific and macroeconomic determinants of Islamic banks profitability in Bangladesh: a panel data approach. Asian Journal of Empirical Research, 8(11), 405-417.

(C) 2018 Asian Economic and Social Society. All rights reserved 


\section{INTRODUCTION}

The bank performance and its determinants have been a widely discussed topic in the area of empirical research because banks play a very consequential role in the national economic magnification. This study fixates on the Islamic banking sector of Bangladesh and endeavors to identify the factors that influence the bank profitability. There are 57 scheduled banks in Bangladesh those operate under full control and supervision of Bangladesh Bank. The financial system in Bangladesh is relatively minute with an under developed banking system. This banking system faces many challenges. Nonperforming loans are at an alarming percentage that lowers the banks' return. NPL ratio stood at 10.10 percent by the end of 2017. The amount of accumulated default loans stood at around 8.67 billion US dollar, which is 12 percent of Bangladesh's total GDP. On the other hand, many banks cannot maintain the standard level of capital to imperil assets ratio prescribed by Basel framework. Some banks maintain a very high Capital to Risk-Asset Ratio (CRAR), where some banks cannot maintain the minimum level of CRAR. Both high and low CRAR affect the caliber of peril and the profitability of banks. In December 2017, Bangladesh banking industry's average CRAR was 10.86 percent. Under Basel III, banks have to maintain 11.2 percent as capital of their jeopardy-weighted assets, which will be 12.19 percent in 2019. In addition, sizably voluminous amount of idle cash in banks' vaults due to less investment opportunities decreases the impress to deposit ratio.

Islamic banking system is conspicuously getting more attention in today's innovative, complex and technology-based banking framework in Bangladesh. The banking industry in Bangladesh is undoubtedly controlled by conventional banks. But over the recent years it has been observed that most of the conventional interest based bank has established a separate Islamic banking wing to offer the Shariah guided activities. There are currently only eight-Islamic Shariah based private commercial banks out of 49 commercial banks operating in Bangladesh. Moreover, 19 conventional banks (including three foreign commercial banks) are currently involved in Islamic banking operations through individual branches and windows which accounted for 22.72 percent of total deposits (108 billion US dollar).

This research paper contributes to the existing literature in following ways: Firstly, most of the studies done on determinants of banking profitability evidenced the conventional commercial banks. A few studies examined the determinants of Islamic banking profitability with such long data base (eight years data which is very rare for this kind of panel study). Secondly, to the best of my knowledge, this is the first paper that applies all the three variations of profitability measurements (ROA, ROE, and NIM) in a single study and tested the relationship of bank-specific as well as macroeconomic variables with each of the profitability measurement separately. Finally, the article presents a systematic application of panel data approach to determine the significance of exogenous variables with respect to each profitability measurement model separately by choosing the best panel data regression model [a choice between fixed versus random effects approach].

Against the backdrop of growth potential of Islamic banking operations in Bangladesh, it becomes imperative in the study to investigate the following research questions:

- What are the company-specific and macro-environment factors that affect the profitability of Islamic banking industry in Bangladesh?

- How does Islamic banking profitability correlate with company-specific and macroenvironment determinants?

\section{LITERATURE REVIEW}

Most of the studies suggest that return on asset (ROA), return on equity (ROE) and net interest margin (NIM) describe the bank profitability accurately (Samad, 2015; Hossain and Ahmed, 2015; Chouikh and Blagui, 2017; Zhang and Dong, 2011; Sufian and Habibullah, 2009). Whether it is a financial organization or a non-financial organization, both ROA and ROE measure an institution's faculty to 
engender earnings from its investments. But they do not precisely represent identically tantamount. Together they provide a better representation of an organization's performance. On the other hand, NIM, which is generally cognate to financial organizations, i.e. bank and non-bank financial institutions gauges the percentage of net interest income over the total earning asset. For Islamic banks, as they do not grant loans, they cannot mention interest income in their income verbal expression, instead they invest in different sectors, get return from the investments and mention investment income in their financial verbal expressions. So, net interest margin is authentically net investment margin for Islamic banks, more concretely net investment income margin.

The profitability of bank is significantly correlated with different bank concrete and macro- level variables. Under the bank concrete variables, highly considered factors are bank size, reserve requisite, capital adequacy ratio, percentage of non-performing loan, liquidity ratio, cost to income ratio and so on. Under external or macro-economic factors, vicissitude in GDP, inflation rate, tax rate, unemployment rate etc. are utilized. Some authors consider dummy variables to optically discern the relationship between profitability and different qualitative factors. General models utilized in the analyses are pooled OLS regression, fine-tuned effect and desultory effect model. Most of the datasets of such studies are panel data and to test whether fine-tuned effect or arbitrary effect model is opportune, the Hausman test is applied. Popular statistical software utilized in the studies is Stata, R Code and SPSS. Excel is not specially designed for statistical analyses and cannot handle all types of data.

Chouikh and Blagui (2017) found that Tunisian bank profitability is negatively correlated with board size. That signifies the more number of officials are present in the board of directors, the lower is the bank performance and vice versa. On the other hand, bank size and privatization have been positively found correlated with bank profitability. The bank specific variables like cost of efficiency, capital to asset ratio, whereas GDP and inflation as macro-level variables do not affect the bank profitability in Tunisia.

Ozili and Uadiale (2017) studied the Nigerian banks profitability applying both static and dynamic panel model and found that high concentrated ownership has positive effect on banks' earnings and the banks with dispersed ownership has the lowest influence on return on assets. Others variables like management efficiency, regulatory based capital ratio, GDP growth rate have not been found significant.

Titko et al. (2015) study the drivers of bank profitability by taking a sample from Latvian and Lithuanian banking sector where they found that there is a statistically consequential positive relationship between bank profitability expressed by ROE and bank size expressed by the volume of deposits. In addition to that a statistically paramount positive relationship is found between cost-toincome ratio and bank profitability expressed by NIM. Their regression analysis designates a negative relationship between commission income as a percentage of total assets and number of branches. The researchers utilize a multiple linear regression analysis as a core method.

Another study by Pervan et al. (2015) states that profitability from the precedent year, bank size, solvency jeopardy, intermediation, industry concentration, market magnification and GDP magnification are statistically paramount variables with a positive influence on bank profitability while variables of credit jeopardy, inflation and operating expenses management has a negative and statistically consequential impact on profitability. The study is conducted for the 2002-2010 period taking the data from Croatian banking industry and ROA is utilized as an endogenous variable in the model of bank profitability. They apply a Generalized Method of Moment estimation proposed by Arellano and Bond.

A study predicated on the banking industry of Bangladesh, Samad (2015) claims that loan deposit ratio, credit jeopardy, capital risk and bank efficiency are consequential factors for determining the profitability of Bangladesh banking industry. Macro-level variables such as inflation rate and market 
structure demeanor are omitted in this study. The author uses ROA to quantify the profitability. Panel Mundane least square is applied for estimating the impact of bank-concrete characteristics and macrolevel variables on bank profitability.

In another study predicated on the banking sector of Bangladesh, Hossain and Ahamed (2015) argue that variables like total interest income, non-interest income, capital, loans \& advances, operating expenditure, deposit, size and non-performing loans have some consequential impact on the profitability. The study uses ROA, ROE and NIM as the quantification of profitability. The study takes top 15 conventional private commercial banks' data from the period of 2012-2016 and banks are culled predicated on the asset size. The authors apply commixed effect model to test the hypotheses.

Petria et al. (2015) consider a sample from EU 27 banking systems to assess the main determinants of banks' profitability. The study highlights that credit and liquidity risk, management efficiency, the diversification of business, the market concentration and the economic growth have influence on bank profitability. The profitability is measured by ROA and ROE. They use the Hausman test to select the appropriate estimation method between fixed effect and random effect model and then reach the decision to use fixed effect model as the appropriate method for their dataset.

In another study predicated on Macedonian banks, Iloska (2014) concludes that profitability is positively affected by productivity, bank size, balance sheet structure, capitalization and non- interest income, and negatively by operating expenses, credit and liquidity peril. In the study, ROA is utilized as the endogenous variable and the author runs simple mundane least squares (OLS) method. The study suggests that development of the Macedonian banking system depends on its efficiency, profitability and competitiveness and banks need to find a way to make the optimal utilization of their resources, while minimizing the expenses and losses.

Zhang and Dong (2011) documented that bank-categorical variables such as capital ratio, loans and deposits are positively correlated to bank performance when the performance is quantified by ROA. When ROE is used as measurement of bank performance, they found a negative relationship between capital ratio and bank profitability. On the other hand, bank size is positively correlated with bank profitability for a small capital based banks and negatively correlated for medium-sized banks.

Sufian and Habibullah (2009) empirically tested the relationship between bank profitability and bank specific and macroeconomic determinants in Bangladesh using the unbalanced panel data. They used ROA, ROE and NIM as measure of bank profitability and found that loans intensity, credit jeopardy, and cost of funds have positive impacts on bank performance, while non- interest income exhibits negative relationship with bank profitability. No macroeconomic variables are found statistically significant to influence the commercial banks profitability in Bangladesh.

Asma et al. (2011) studied the determinants of Islamic bank profitability in Malaysia. They considered bank-specific factors of size, capital adequacy ratio, liquidity and expenditure management and results exhibit that only the size of bank assets can statistically influence the profitability of the banks. In another study made by Ahmad and Ahmad (2004) documented that bank assets size, capital risk-based assets ratio as well as management efficiency positively affect the Islamic bank profitability in Malaysia.

\section{DATA AND METHODOLOGY}

Eight-year (2010-2017) data of eight Islamic banks from the banking industry of Bangladesh are taken for the study. Data that utilized in the study are secondary data. Company concrete data are amassed from the annual reports of the banks. The data for most of the variables are collected from respective banks' annual reports. Data related to few variables managed from Bangladesh bank annual publications. For the bank size, natural logarithm of total asset is considered. Macro- level data are accumulated from World Bank Database. There are two basic types of panel data analysis: One is 
where relatively large $\mathrm{N}$, small $\mathrm{T}$ and other is relatively small $\mathrm{N}$, large $\mathrm{T}$. Conceptually both can be similar but in the estimation process particularly the statistical properties of the model estimates are somewhat vary with the asymptotic proposition like either $\mathrm{N}$ or $\mathrm{T}$ approaches to infinity. The data set for the current study do not satisfy any of these formats. Because there are only eight-private commercial banks (out of 49 commercial banks) providing as full-fledged Islamic banking services. In the study, we attempted only Islamic banking operations and thus we used eight years data to have a consistent and effective estimation from the specified panel data models. Another reason was that to get data for some variables for all the banks beyond 2010 was unavailable. One bank started its operation in 2012 and other bank had missing data for some major variables.

\subsection{Hypothesis formulation}

Seven hypotheses are formed for the study. A hypothesis will be completely accepted if the coefficient estimate is statistically significant and its sign is shown as expected. It will be partially accepted if the coefficient estimate is not statistically significant but the sign is as predicted. Otherwise, a hypothesis will be rejected.

\section{Table 1: List of hypotheses}

\begin{tabular}{ll}
\hline Null Hypothesis & \multicolumn{1}{c}{ Description } \\
\hline H1: & Profitability is positively and significantly correlated to bank size \\
H2: & Profitability is negatively and significantly correlated to capital to risk assets \\
H3: & Profitability is positively and significantly correlated to investment to deposit ratio \\
H4: & Profitability is negatively and significantly correlated to non-performing investment \\
H5: & Profitability is negatively and significantly correlated to operating efficiency \\
H6: & Profitability is positively and significantly correlated to inflation rate \\
H7: & Profitability is positively and significantly correlated to GDP growth \\
\hline
\end{tabular}

\subsection{General model of the study}

The general model attempts to measure the relationship between the endogenous variable (bank profitability) and the exogenous variables (company specific and macro-environment). The general model is estimated by the following equation:

\section{PROFITABILITYt $=f($ SIZEt, CRARt, LIQUIDITYt, NPIt, EFFICIENCYt, INFLATIONt, GROWTHt $)$}

Where, profitability is a function of all these seven variables at time t. Three specific models are established to express three endogenous variables taken for the study.

\section{Model 1}

The first model of the study estimates the statistical relationship between the endogenous variable ROA and the seven exogenous variables. The equation is as follows:

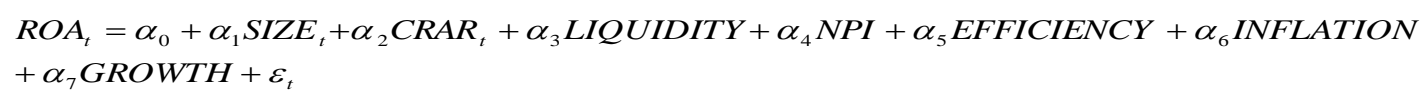

Where $\alpha_{0}$ is the intercept or constant of the model, $\alpha \mathrm{k}(\mathrm{k}=1,2,3, \ldots, 7)$ are the coefficients to be estimated, and $U_{t}$ is the error term of the equation.

\section{Model 2}

The second model of the study estimates the statistical relationship between the endogenous variable ROE and the seven exogenous variables. The equation is as follows:

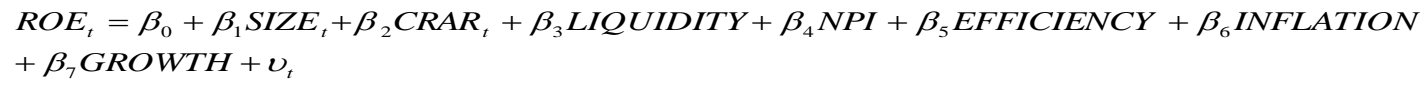


Where $\beta_{0}$ is the intercept or constant of the model, $\beta_{\mathrm{k}}(\mathrm{k}=1,2,3, \ldots, 7)$ are the coefficients to be estimated and $V_{t}$ is the error term of the equation.

\section{Model 3}

The third model of the study estimates the statistical relationship between the endogenous variable NIM and the seven exogenous variables. The equation is as follows:

$$
\begin{aligned}
& \operatorname{NIM}_{t}=\gamma_{0}+\gamma_{1} \operatorname{SIZE}_{t}+\gamma_{2} \mathrm{CRAR}_{t}+\gamma_{3} \text { LIQUIDITY }+\lambda_{4} N P I+\lambda_{5} \text { EFFICIENCY }+\gamma_{6} I N F L A T I O N \\
& +\gamma_{7} G R O W T H+\omega_{t}
\end{aligned}
$$

Where $\gamma_{0}$ is the intercept or constant of the model, $\gamma_{\mathrm{k}}(\mathrm{k}=1,2,3, \ldots, 7)$ are the coefficients to be estimated and $W_{t}$ is the error term of the equation.

A significantly positive coefficient estimate shows a statistically significant positive relationship between the bank profitability and the corresponding factors. On the other hand, a significantly negative coefficient estimate shows a statistically significant negative relationship between the bank profitability and the corresponding factors.

\subsection{Specification of Variables}

\subsubsection{Endogenous variables}

Three endogenous variables are taken as a measure of profitability. Most of the studies (Samad, 2015; Hossain and Ahmed, 2015; Chouikh and Blagui, 2017; Zhang and Dong, 2011; Sufian and Habibullah 2009; Sufian, 2009) claim that these three variables can well explain the profitability of a banking organization.

\subsubsection{Return on assets (ROA)}

Return on Assets equals net income after tax divided by total assets over a given period. A ROA of $5 \%$ means that the company generates tk.5 of net profit by employing every tk.100 of assets. The higher the ROA, the more efficient the company about using its assets.

\subsubsection{Return on equity (ROE)}

Return on Equity equals net income divided by total common equity over a given period. A ROE of $10 \%$ means that the common stockholders have earned tk. 10 for every tk. 100 invested in the company. The higher the ROE, the more efficient the company about employing its equity.

\subsubsection{Net Investment margin (NIM)}

The ratio is only relevant for financial organizations. NIM is commonly known as Net Interest Margin for conventional banking organizations. In Islamic banking, net Investment Margin equals investment income minus profit paid on deposits divided by total profit earning assets over a given period. Simply put, NIM is the net investment income relative to the total amount of profit earning assets. The major portion of Islamic bank's profit earning assets consist of long term and short term investments. A NIM of 3 percent means that the company generates tk. 3 of net investment income by employing every tk.100 of profit earning assets. For conventional banking organizations, the ratio equals interest income minus interest expense divided by total interest earning assets.

Table 2: List of endogenous variables

\begin{tabular}{ll}
\hline \multicolumn{1}{c}{ Endogenous Variables } & \multicolumn{1}{c}{ Formula } \\
\hline Return on Asset (ROA) & Net Income/Total Asset \\
Return on Equity (ROE) & Net Income/Total Equity \\
Net Investment Margin (NIM) & Net Investment/Profit Earning Asset \\
\hline
\end{tabular}




\subsection{Exogenous variables}

Total seven variables are considered as independent factors. These variables are classified into two sections, company specific or micro-economic exogenous variables and environment specific or macro-level exogenous variables. Five company specific and two macro-level variables are taken for this study. The studies of (Asma et al., 2011; Ahmad and Ahmad, 2004; Bashir, 2003) suggest that bank size, capital to risk assets ratio, liquidity, non-performing loans, management efficiency have significant impacts on the profitability of a banking institution. On the other hand, studies made by (kosmidou et al., 2005; Athanasoglou et al., 2008) documented that GDP growth and inflation can have significant effect on banks profitability.

\subsection{Bank specific exogenous variables}

\subsubsection{Size}

Natural logarithm of total assets over a given period is considered as the size of an organization. For a banking institution, studies argue that logarithm of total investments or logarithm of total deposits can also be taken as the size of a bank. It is expected that the large the size of a bank, the more profitable it is. Because a large bank can attain economy of scale and can reduce the operating cost. Therefore, it is expected that $\partial \pi / \partial \mathrm{SIZE}>0$.

\subsubsection{Capital to risk assets ratio (CRAR)}

CRAR equals bank's Tier 1 capital plus Tier 2 capital divided by total risk weighted assets over a given period. Tier 1 capital is bank's core capital, i.e. common equity and retained earnings. Tier 2 capital is bank's supplementary capital, i.e. subordinated debt instruments. Total risk weighted assets are calculated by multiplying bank's earning assets by appropriate risk-weight. For example, an Islamic bank can assign $100 \%$ risk weight to corporate investments and $20 \%$ risk weight to interbank deposits. CRAR ensures the efficiency and stability of a nation's financial system by lowering the risk of banks becoming insolvent. The ratio is calculated under the Basel III framework. Under the latest framework, current CRAR standard is $11.2 \%$ for all banks. The higher the ratio, the higher the risk aversion of a bank and the higher risk aversion means low profits. So, it is expected that $\partial \pi / \partial \mathrm{CRAR}<0$.

\subsubsection{Liquidity}

The liquidity of a bank can be measured by several ratios. In this study, investment to deposit ratio over a given period is taken as a measure of bank's liquidity. The ratio can be assessed by dividing the bank's total investments by its total deposits. In conventional banking, it is called loan to deposit ratio. A high ratio means that the bank may not have enough liquidity to cover any unforeseen fund requirements. At the same time, when a bank transforms a higher percentage of its deposit into investments, the bank is expected to generate more profits, thus $\partial \pi / \partial$ LIQUIDITY $>0$.

\subsubsection{Non-performing investment (NPI)}

Percentage of NPI equals non-performing investment divided by total investment over a given period. Non-performing investment is also called classified investment. In conventional banking, nonperforming investment is called non-performing loan (NPL) or classified loan. It is the best measure of bank's credit risk. The higher the NPI, the lower the profit, therefore, $\partial \pi / \partial \mathrm{NPI}<0$.

\subsubsection{Operating efficiency}

Operating Efficiency is calculated by dividing the operating expense by operating income over a given period. It is also called cost to income ratio. It shows how efficiently a bank can generates profit from its operations. It is expected that the higher the operating expense per dollar of income, the lower the bank profit, so, $\partial \pi / \partial \mathrm{EFFICIENCY}<0$. 
Table 3: List of bank specific exogenous variables

\begin{tabular}{llc}
\hline $\begin{array}{l}\text { Bank Specific Exogenous } \\
\text { Variables }\end{array}$ & \multicolumn{1}{c}{ Formula } & Expected Effect \\
\hline Size & Natural Logarithm of Total Asset & + \\
Capital to Risk Assets (CRAR) & Capital/Risk Weighted Assets & - \\
Liquidity & Total Investment/Total Deposit & + \\
Non-Performing Investment (NPI) & Non-Performing Investment/Total Investment & - \\
Efficiency & Operating Expense/Operating Income & - \\
\hline
\end{tabular}

\subsection{Macro-Level Exogenous Variables}

\subsubsection{GDP growth}

Nominal GDP growth equals recent year GDP divided by previous year GDP minus 1 . Then it is adjusted to inflation to get the real GDP growth. Studies suggest that the growth of economy creates more opportunities for investments and when more investments are made, the profitability of bank is expected to increase, thus $\partial \pi / \partial \mathrm{GROWTH}>0$.

\subsubsection{Inflation}

Consumer Price Index (CPI) is a popular measure of inflation. The higher the inflation rate, the higher is the interest rate. It is expected that higher interest rate increases banks' profitability as the interest rate spread will increase, therefore, $\partial \pi / \partial \mathrm{INFLATION}>0$.

Table 4: List of macro-level exogenous variables

\begin{tabular}{lcc}
\hline Macro-Level Exogenous Variable & Source & Expected Effect \\
\hline Growth & World Bank Database & + \\
Inflation & World Bank Database & + \\
\hline
\end{tabular}

\section{EMPIRICAL ANALYSIS AND FINDINGS}

For the kind of data set used in the study, panel approach is appropriate research model. Researchers generally use three panel data methods. They are pooled regression, fixed effect or LSDV model and random effect model. If the pooled regression is used, it will not distinguish between the various banks rather combine all the banks together and will deny the heterogeneity or individuality that may exist among the eight banks. On the other hand, fixed effect model allows the heterogeneity or individuality among the banks by allowing to have its own intercept value. If all the banks have a common mean value for the intercept, the random effect model will be appropriate. The pooled regression model will not be considered for this study due to its major pitfall. The study will use fixed effect model or random effect model to estimate the relationships among endogenous and exogenous variables.

We first find out that which method (fixed effect or random effect) is accurate for each of the models used in the study separately by applying Hausman test and then run each panel data regression model to assess the influence of bank-specific and macroeconomic variables of Islamic banks profitability. The hypotheses will be checked at a significance level of 0.05 . This study uses Stata 13 to run all the tests and model equations.

\subsection{Result from Hausman test for model one (ROA)}

The null hypothesis is random effect is appropriate. We should accept the null hypothesis if probability values come from hausman test is greater than 5 percent significance level meaning that we shall apply the random effect model. 
Table 5: Hausman test result for model one

\begin{tabular}{lcccc}
\hline $\begin{array}{l}\text { Variables } \\
\text { Size }\end{array}$ & Fixed & Random & $\begin{array}{c}\text { Coefficients } \\
\text { Difference }\end{array}$ & sqrt(diag(V_b-V_B $)$ ) \\
\hline CRAR & -0.0160 & -0.0001 & -0.0159 & 0.0028 \\
LIQUIDITY & -0.0558 & -0.1165 & 0.0606 & \\
LIQUIDITY & 0.0436 & -0.0694 & 0.1130 & 0.0542 \\
NPI & 0.2295 & -0.2527 & 0.4823 & \\
EFFICIENCY & -0.0013 & 0.0017 & -0.0030 & \\
INFLATION & -0.0546 & 0.0219 & -0.0765 & \\
GROWTH & 0.1016 & -0.6679 & 0.7696 & \\
Prob>chi2 $=$ & 0.0000 & & &
\end{tabular}

As probability value is less than the 5 percent null hypothesis has been rejected meaning that we will apply the random effect for the first model.

\subsection{Fixed effect results for model one parameter}

Table 6: Fixed effect Results for Model One

\begin{tabular}{lcccccc}
\hline ROA & Coef. & Std. Err. & $\mathbf{t}$ & $\mathbf{P}>|\mathbf{t}|$ & \multicolumn{2}{c}{ [95\% Conf. Interval] } \\
\hline SIZE & -0.0160 & 0.0040 & -4.00 & 0.000 & -0.0242 & -0.0079 \\
CRAR & -0.0558 & 0.0175 & -3.19 & 0.003 & -0.0913 & -0.0204 \\
LIQUIDITY & 0.0436 & 0.0221 & 1.97 & 0.056 & -0.0011 & 0.0884 \\
NPI & 0.2295 & 0.0648 & 3.54 & 0.001 & 0.0984 & 0.3607 \\
EFFICIENCY & -0.0013 & 0.0057 & -0.23 & 0.820 & -0.0129 & 0.0102 \\
INFLATION & -0.0546 & 0.0877 & -0.62 & 0.537 & -0.2321 & 0.1228 \\
GROWTH & 0.1016 & 0.2935 & 0.35 & 0.731 & -0.4925 & 0.6958 \\
Cons & 0.3485 & 0.0883 & 3.95 & 0.000 & 0.1697 & 0.5273 \\
Prob>F=0.0000 & & & & & & \\
\hline
\end{tabular}

\subsection{Hypothesis acceptance or rejection based on model 1}

Table 7: Summary result for model one

\begin{tabular}{lccccc}
\hline Hypothesis & $\begin{array}{c}\text { Exogenous } \\
\text { Variables }\end{array}$ & $\begin{array}{c}\text { Statistical } \\
\text { Significance }\end{array}$ & $\begin{array}{c}\text { Expected } \\
\text { Effect }\end{array}$ & $\begin{array}{c}\text { Estimated } \\
\text { Effect }\end{array}$ & Result \\
\hline H1 & Bank Size & Significant & Positive & Negative & Rejected \\
H2 & $\begin{array}{c}\text { Capital to Risk } \\
\text { Assets }\end{array}$ & Significant & Negative & Negative & Accepted \\
H3 & Liquidity & Significant & Positive & Positive & Accepted \\
H4 & $\begin{array}{c}\text { Non-Performing } \\
\text { Investment }\end{array}$ & Significant & Negative & Positive & Rejected \\
H5 & Operating Efficiency & Insignificant & Negative & Negative & Partially \\
H6cepted
\end{tabular}




\subsection{Hausman test result for model 2 (ROE)}

Table 8: Hausman test result for model two

\begin{tabular}{lcccc}
\hline & $(\mathbf{b})$ & $(\mathbf{B})$ & $(\mathbf{b}-\mathbf{B})$ & sqrt(diag(V_b-V_B $))$ \\
& Fixed & Random & Difference & S.E. \\
\hline SIZE & -0.0283 & -0.0001 & -0.0282 & 0.0210 \\
CRAR & -0.0271 & -0.0360 & 0.0090 & 0.0526 \\
LIQUIDITY & 0.6206 & 0.6228 & -0.0022 & 0.0902 \\
NPI & -0.1651 & -0.0563 & -0.1087 & 0.3467 \\
EFFICIENCY & -0.0450 & -0.0423 & -0.0027 & 0.0180 \\
INFLATION & -0.3656 & 0.0591 & -0.4247 & 0.2798 \\
GROWTH & -1.8294 & -3.1946 & 1.3652 & 1.1080 \\
Prob>chi2 $=$ & 0.8647 & & & \\
\hline
\end{tabular}

Hausman test results indicate that we failed to reject the null hypothesis and thus random effect model is appropriate for model two.

\subsection{Random effect results for model two parameter}

Table 9: Random effect results for model two

\begin{tabular}{lccccc}
\hline ROE & Coef. & Std. Err. & $\mathbf{t}$ & $\mathbf{P}>|\mathbf{z}|$ & [95\% Conf. Interval] \\
\hline SIZE & -0.0001 & 0.0080 & -0.02 & 0.988 & -0.0158 \\
CRAR & -0.0360 & 0.0826 & -0.44 & 0.663 & -0.1980 \\
LIQUIDITY & 0.6228 & 0.0845 & 7.37 & 0.000 & -0.4572 \\
NPI & 0.0563 & 0.1043 & -0.54 & 0.589 & -0.2608 \\
EFFICIENCY & -0.0423 & 0.0263 & -1.61 & 0.108 & -0.0939 \\
INFLATION & 0.0591 & 0.4022 & 0.15 & 0.883 & -0.7292 \\
GROWTH & -3.1946 & 1.2095 & -2.64 & 0.008 & -5.5652 \\
_cons & -0.1760 & 0.1997 & -0.88 & 0.378 & -0.5674 \\
Prob>chi2-0.000 & & & & & \\
\hline
\end{tabular}

4.6. Hypothesis acceptance or rejection based on model 2

Table 10: Summary result for model two

\begin{tabular}{lccccc}
\hline Hypothesis & $\begin{array}{c}\text { Exogenous } \\
\text { Variables }\end{array}$ & $\begin{array}{c}\text { Statistical } \\
\text { Significance }\end{array}$ & $\begin{array}{c}\text { Expected } \\
\text { Effect }\end{array}$ & $\begin{array}{c}\text { Estimated } \\
\text { Effect }\end{array}$ & Result \\
\hline H1 & Bank Size & Insignificant & Positive & Negative & Rejected \\
H2 & $\begin{array}{c}\text { Capital to Risk } \\
\text { Assets }\end{array}$ & Insignificant & Negative & Negative & $\begin{array}{c}\text { Partially } \\
\text { Accepted }\end{array}$ \\
H3 & Liquidity & Significant & Positive & Positive & Accepted \\
H4 & $\begin{array}{c}\text { Non-Performing } \\
\text { Investment }\end{array}$ & Insignificant & Negative & Negative & $\begin{array}{c}\text { Partially } \\
\text { Accepted }\end{array}$ \\
H5 & $\begin{array}{c}\text { Operating } \\
\text { Efficiency }\end{array}$ & Insignificant & Negative & Negative & $\begin{array}{c}\text { Partially } \\
\text { Accepted }\end{array}$ \\
H6 & Inflation & Insignificant & Positive & Positive & $\begin{array}{c}\text { Partially } \\
\text { Accepted }\end{array}$ \\
H7 & GDP Growth & Significant & Positive & Negative & Rejected \\
\hline
\end{tabular}




\subsection{Hausman test result for model three (NIM)}

Table 11: Hausman test result for model three

\begin{tabular}{lcccc}
\hline & $\begin{array}{c}(\mathbf{b}) \\
\text { Fixed }\end{array}$ & $\begin{array}{c}(\mathbf{B}) \\
\text { Random }\end{array}$ & $\begin{array}{c}(\mathbf{b}-\mathbf{B}) \\
\text { Difference }\end{array}$ & $\begin{array}{c}\text { sqrt }\left(\mathbf{d i a g}\left(\mathbf{V} \_\mathbf{b}-\mathbf{V}_{-} \mathbf{B}\right)\right) \\
\text { S.E. }\end{array}$ \\
\hline SIZE & 0.0030 & 0.0037 & -0.0006 & 0.0023 \\
CRAR & -0.0058 & 0.0053 & -0.0110 &. \\
LIQUIDITY & -0.0051 & 0.0079 & -0.0129 & 0.0084 \\
NPI & -0.0512 & 0.0236 & -0.0748 & 0.0406 \\
EFFICIENCY & -0.0137 & -0.0135 & -0.0002 &. \\
INFLATION & -0.0238 & 0.0031 & -0.0269 &. \\
GROWTH & 0.3173 & 0.3031 & 0.0141 & 0.0827 \\
Prob>chi2 $=$ & 0.9998 & & & \\
\hline
\end{tabular}

Here we also failed to reject the null hypothesis and thus random effect model will be applied for third model.

\subsection{Random effect results for model three parameter}

Table 12: Random effect results for model three

\begin{tabular}{lcccccc}
\hline NIM & Coef. & Std. Err. & $\mathbf{z}$ & $\mathbf{P}>|\mathbf{z}|$ & [95\% Conf. Interval] \\
\hline SIZE & 0.004 & 0.001 & 2.480 & 0.013 & 0.001 & 0.007 \\
CRAR & 0.005 & 0.012 & 0.430 & 0.667 & -0.019 & 0.029 \\
LIQUIDITY & 0.008 & 0.012 & 0.640 & 0.521 & -0.016 & 0.032 \\
NPI & 0.024 & 0.016 & 1.490 & 0.136 & -0.007 & 0.055 \\
EFFICIENCY & -0.014 & 0.004 & -3.400 & 0.001 & -0.021 & -0.006 \\
INFLATION & 0.003 & 0.059 & 0.050 & 0.958 & -0.113 & 0.119 \\
GROWTH & 0.303 & 0.179 & 1.690 & 0.091 & -0.048 & 0.654 \\
-cons & -0.081 & 0.036 & -2.240 & 0.025 & -0.151 & -0.010 \\
Prob>chi2=0.000 & & & & & & \\
\hline
\end{tabular}

4.9. Hypothesis acceptance or rejection based on model 3

Table 13: Summary result for model three

\begin{tabular}{lccccc}
\hline Hypothesis & $\begin{array}{c}\text { Exogenous } \\
\text { Variables }\end{array}$ & $\begin{array}{c}\text { Statistical } \\
\text { Significance }\end{array}$ & $\begin{array}{c}\text { Expected } \\
\text { Effect }\end{array}$ & $\begin{array}{c}\text { Estimated } \\
\text { Effect }\end{array}$ & Result \\
\hline H1 & $\begin{array}{c}\text { Bank Size } \\
\text { Capital to Risk } \\
\text { Assets }\end{array}$ & $\begin{array}{c}\text { Significant } \\
\text { Insignificant }\end{array}$ & Positive & Positive & Accepted \\
H3 & $\begin{array}{c}\text { Liquidity } \\
\text { Non-Performing } \\
\text { Investment }\end{array}$ & Insignificant & Positive & Positive & Rejected \\
H4 & $\begin{array}{c}\text { Operating } \\
\text { Efficiency }\end{array}$ & Significant & Negative & Negative & Accepted \\
H5 & Inflation & Insignificant & Positive & Positive & $\begin{array}{c}\text { Partially } \\
\text { Accepted } \\
\text { H6 }\end{array}$ \\
H7 & GDP Growth & Insignificant & Positive & Positive & $\begin{array}{c}\text { Partially } \\
\text { Accepted }\end{array}$ \\
\hline
\end{tabular}


The robustness of each model has been tested applying the Pesaran's test of cross sectional independence to explore whether residuals generated from panel data regression are correlated across the banks. The results suggest that null hypothesis of there is no serial correlation has been accepted in each of the three models as probability value is greater than 5 percent significance level. Therefore, it can be said that each model is good to estimate the determinants of Islamic Banks profitability in Bangladesh.

\section{CONCLUSION}

This study aims to ascertain the determinants of Islamic banking profitability in Bangladesh over a period of 2010-2017 and tries to find out the relationship between the bank profitability and several bank specific and macroeconomic variables. Bank profitability is quantified by ROA, ROE and NIM, and consequently, three models are proposed. The study applied panel data fine-tuned effect model and desultory effect model to estimate all three equations. At the beginning, Hausman test has been applied to identify which method (Random versus fixed) is appropriate for each of the specified panel models developed and then run the regression model to estimate the influence of bank profitability. Empirical results indicated that capital to assets and liquidity ratios are statistically significant when bank profitability is quantified by ROA. On the other hand, only liquidity has positive effect when bank profitability is measured by return on equity whereas, bank size and operating efficiency are found to be statistically significant and have the consistent sign when bank profitability is quantified by net investment margin. Nonperforming investment, inflation and GDP growth do not have any statistically significant influence on Islamic bank profitability in any of three specific models applied in the study. Finally, Pesaran's test of cross sectional independence is done to explore whether residuals generated from panel data regression are correlated across the banks. No serial correlation has been observed in all the three panel data models to assess whether the bank specific and macroeconomic determinants have any influence on Islamic bank profitability.

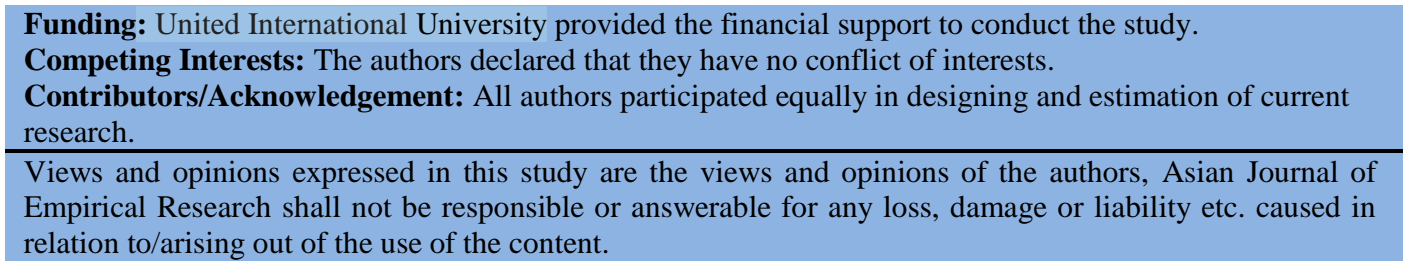

\section{References}

Ahmad, N. H., \& Ahmad, S. N. (2004). Key factors influencing credit risk of Islamic bank: a Malaysian case. The Journal of Muamalat and Islamic Finance Research, 1(1), 65-80. view at Google scholar

Asma, I., Fadli, A., \& Noor, T. (2011). Determinant of Islamic banking institutions' profitability in Malaysia. Word Applied Sciences Journal, 12(1), 1-7. view at Google scholar

Athanasoglou, P. P., Brissimis, S. N., \& Delis, M. D. (2008). Bank-specific, industry-specific and macroeconomic determinants of bank profitability. Journal of International Financial Markets, Institutions and Money, 18(2), 121-136. view at Google scholar / view at publisher

Bashir, A. H. M. (2003). Determinants of profitability in Islamic banks: Some evidence from the Middle East. Islamic Economic Studies, 11(1), 31-57. view at Google scholar

Chouikh, A., \& Blagui, Y. (2017). The determinants of bank performance: the case of Tunisian listed banks. Journal of Finance and Accounting, 5(2), 53-60. view at Google scholar / view at publisher

Hossain, M. S., \& Ahamed, F. (2015). Determinants of bank profitability: a study on the banking sector of Bangladesh. Journal of Finance and Banking, 13(1 \& 2), 43-57. view at Google scholar / view at publisher

Iloska, N. (2014). An analysis of bank profitability in Macedon. Journal of Applied Economics and Business, 2(1), 31-50. view at Google scholar 
Kosmidou, K., Tanna, S., \& Pasiouras, F. (2005). Determinants of profitability of domestic UK commercial banks: Panel evidence from the period 1995-2002. In money macro and finance (MMF) research group conference, 45, 1-27. view at Google scholar

Ozili, P., \& Uadiale, O. (2017). Ownership concentration and bank profitability. Future Business Journal, 3, 159-171. view at Google scholar / view at publisher

Pervan, M., Iva, P., \& Josip, A. (2015). Profit persistence and determinants of bank profitability in Croatia. Economic Research-Ekonomska Istraživanja, 28(1), 284-298. view at Google scholar / view at publisher

Petria, N., Capraru, B., \& Ihnatov, I. (2015). Determinants of banks' profitability: evidence from EU 27 banking systems. Procedia Economics and Finance, 20, 518-524. view at Google scholar / view at publisher

Samad, A. (2015). Determinants bank profitability: empirical evidence from Bangladesh commercial banks. International Journal of Financial Research, 6(3), 173-179. view at Google scholar I view at publisher

Sufian, F. (2009). Determinants of non-bank financial institutions profitability: empirical evidence from Malaysia. Global Business and Economics Review, 11(2), 141. view at Google scholar I view at publisher

Sufian, F., \& Habibullah, M. S. (2009). Determinants of bank profitability in a developing economy: Empirical evidence from Bangladesh. Journal of Business Economics and Management, 10(3), 207-217. view at Google scholar / view at publisher

Titko, J., Skvarciany, V., \& Jureviciene, D. (2015). Drivers of bank profitability: case of Latvia and Lithuania. Intellectual Economics, 9, 120-129. view at Google scholar / view at publisher

Zhang, C., \& Dong, L. (2011). Determinants of bank profitability: evidence from the U.S banking sector. Research Project Submitted in Partial Fulfillment of the Requirements for the Degree of Master of Financial Risk Management. Simon Fraser University. view at Google scholar 